\title{
Natural variation of selenium in Brazil nuts and soils from the Amazon region
}

\author{
E.C. Silva Junior ${ }^{\text {a }}$, L.H.O. Wadt ${ }^{\text {b }}$, K.E. Silva ${ }^{c}$, R.M.B. Lima ${ }^{c}$, K.D. Batista ${ }^{\text {d }}$, M.C. Guedes ${ }^{\text {e }}$, \\ G.S. Carvalho ${ }^{\text {a }}$, T.S. Carvalho ${ }^{\text {a }}$, A.R. Reis ${ }^{f}$, G. Lopes ${ }^{a}$, L.R.G. Guilherme ${ }^{\text {a, * }}$ \\ a Department of Soil Science, Federal University of Lavras, Lavras, MG, CEP: 37200-000, Brazil \\ ${ }^{\mathrm{b}}$ Embrapa Rondônia, Porto Velho, RO, CEP: 76815-800, Brazil \\ ${ }^{\mathrm{c}}$ Embrapa Amazônia Ocidental, Manaus, AM, CEP: 69010-970, Brazil \\ ${ }^{\mathrm{d}}$ Embrapa Roraima, Boa Vista, RR, CEP: 69301-970, Brazil \\ e Embrapa Amapá, Macapá, AP, CEP: 68903-419, Brazil \\ ${ }^{\mathrm{f}}$ Engenharia de Biossistemas, São Paulo State University, Tupã, SP, CEP: 17602-496, Brazil
}

\section{H I G H L I G H T S}

- Not all Brazil nuts are selenium-rich.

- Se levels in soils from Amazon region are below the toxic level.

- Se content in Brazil nuts are influenced by soil pH.

- Se contents in Brazil nuts varied widely among and within tree populations.

\section{A R T I C L E I N F O}

\section{Article history:}

Received 28 April 2017

Received in revised form

23 August 2017

Accepted 25 August 2017

Available online 4 September 2017

Handling Editor: Patryk Oleszczuk

\section{Keywords:}

Selenium availability

Bertholletia excelsa

Genotypic variation

Amazon rainforest

Nutrition

Selenium accumulation

\begin{abstract}
A B S T R A C T
Brazil nut tree (Bertholletia excelsa) is native of the Amazon rainforest. Brazil nuts are consumed worldwide and are known as the richest food source of selenium (Se). Yet, the reasoning for such Se contents is not well stablished. We evaluated the variation in Se concentration of Brazil nuts from Brazilian Amazon basin, as well as soil properties, including total Se concentration, of the soils sampled directly underneath the trees crown, aiming to investigate which soil properties influence Se accumulation in the nuts. The median Se concentration in Brazil nuts varied from $2.07 \mathrm{mg} \mathrm{kg}^{-1}$ (in Mato Grosso state) to $68.15 \mathrm{mg} \mathrm{kg}^{-1}$ (in Amazonas state). Therefore, depending on its origin, a single Brazil nut could provide from $11 \%$ (in the Mato Grosso state) up to $288 \%$ (in the Amazonas state) of the daily Se requirement for an adult man $(70 \mu \mathrm{g})$. The total Se concentration in the soil also varied considerably, ranging from $<65.76$ to $625.91 \mu \mathrm{g} \mathrm{kg}-1$, with highest Se concentrations being observed in soil samples from the state of Amazonas. Se accumulation in Brazil nuts generally increased in soils with higher total Se content, but decreased under acidic conditions in the soil. This indicates that, besides total soil Se concentration, soil acidity plays a major role in Se uptake by Brazil nut trees, possibly due to the importance of this soil property to Se retention in the soil.
\end{abstract}

(C) 2017 Elsevier Ltd. All rights reserved.

\section{Introduction}

The Brazil nut tree (Bertholletia excelsa) is native to South America and grows in upland and well-drained areas throughout the Brazilian Amazon rainforest, as well as in adjacent areas of Bolivia, Peru, Colombia, Venezuela, and Guyana (Shepard and

\footnotetext{
* Corresponding author.

E-mail address: guilherm@dcs.ufla.br (L.R.G. Guilherme).
}

Ramirez, 2011). Brazil nuts are consumed worldwide because of their high protein (15\%), carbohydrate (9\%), and lipid (71\%) contents, as well as their frequently high selenium (Se) content $\left(290.5 \mu \mathrm{g} \mathrm{g}^{-1}\right.$ in average) (Stockler-Pinto et al., 2015), making them the richest known food source of Se, with concentrations up to $512 \mu \mathrm{g} \mathrm{g}^{-1}$ being reported in the literature (Chang et al., 1995; Dumont et al., 2006).

Selenium is an essential nutrient for humans and other organisms, including bacteria and algae (Rayman, 2012; Vriens et al., 2016). As a constituent of 25 selenoproteins, it plays key roles in 
the immune system, reduces viral infections, is essential for fertility and reproduction, acts in the metabolism of thyroid hormone, prevents cardiovascular disease, and possibly alleviates oxidative stress or inflammatory conditions in the human body (Rayman, 2012). Se content in food is determined by the occurrence and bioavailability of this element in the soil and by the efficiency of the soil-plant transfer system, both of which are highly variable worldwide. Thus, the Se nutritional status of human populations is usually geographically correlated, and agronomic biofortification has been proposed for various crops and regions to alleviate Se deficiency in humans (Winkel et al., 2015; Nothstein et al., 2016).

The intake of Se via consumption of Brazil nuts has been shown to have anti-inflammatory and antioxidant effects on patients under hemodialysis, improving glutathione peroxidase (GPx) activity, and thyroid hormone profile (Stockler-Pinto et al., 2014, 2015). Also, the consumption of Brazil nuts can improve both Se status and lipid profile, which has effects on the high-density lipoprotein cholesterol levels, and is thereby used by obese people to reduce risks associated with cardiovascular disease (Cominetti et al., 2012). The current recommended daily intake of Se has been established as $70 \mu \mathrm{g} \mathrm{day}^{-1}$ for adult men and $60 \mu \mathrm{g} \mathrm{day}^{-1}$ for adult women, while the suggested upper safe limit of Se intake is set at $400 \mu \mathrm{g} \mathrm{day}^{-1}$ (Kipp et al., 2015; Institute of Medicine, 2000). An acceptable threshold for Se toxicity is $850-900 \mu \mathrm{g} \mathrm{day}^{-1}$, and excessive Se intake could result in adverse health problems, including symptoms such as loss of hair and nails, skin lesions, disorders of the nervous system and even paralysis and death (Bajaj et al., 2011; Lemire et al., 2012). On the other hand, at very low levels of Se intake (where the usual intake for adults is $<20 \mu \mathrm{g} \mathrm{Se} \mathrm{day}^{-1}$ ) clinical deficiency disorders have been reported, including Keshan disease (cardiomyopathy), and the Kashin-Beck disease (osteoarthropathy) (Chilimba et al., 2011).

Selenium concentration in Brazil nuts can vary by about three orders of magnitude $\left(0.2-512.0 \mathrm{mg} \mathrm{kg}^{-1}\right)$ across several regions of South America (Chang et al., 1995; Secor and Lisk, 1989; Pacheco and Scussel, 2007; Parekh et al., 2008) and it has been speculated that this variation is mainly associated with differences in Se concentration in the soil (Reilly, 1999; Secor and Lisk, 1989). However, little is known about selenium concentration in these soils, with only a few studies in agricultural soils from the Amazon region reporting Se concentrations ranging from $419 \mu \mathrm{g} \mathrm{kg}^{-1}$ (in the state of Pará) to $604 \mu \mathrm{g} \mathrm{kg}^{-1}$ (in the state of Amazonas) (Shaltout et al., 2011) and in the tributaries of the Orinoco river, Venezuela, ranging from 60 to $5163 \mu \mathrm{g} \mathrm{kg}^{-1}$ (Yee et al., 1987). In addition, no systematic assessment of the relationship between Se concentration in Brazil nuts and in the soil has yet been reported.

Besides total Se concentration in the soil, selenium availability to plants is controlled by a number of other soil biophysico chemical parameters, including prevailing $\mathrm{pH}$ and redox potential conditions, Se speciation, texture, mineralogy, microbial activity, organic matter content, and the presence of competing ions (Fordyce, 2007; Tolu et al., 2014; Li et al., 2017). For the highly weathered tropical soils, rich in iron and aluminum oxides in the clay fraction, Se adsorption increases with increasing clay content, reducing its availability to plants (Abreu et al., 2011). On the other hand, $\mathrm{P}$ and $\mathrm{S}$ fertilization can reduce Se adsorption and thus increase its availability (Lessa et al., 2016). Finally, considering that the soil charges in tropical soils are predominantly $\mathrm{pH}$ dependent, we hypothesized that soil acidity have a major influence on Se adsorption and, consequently, on Se uptake by Brazil nut trees.

In this study, we aimed to investigate whether the natural variation of Se in Brazil nuts from different Amazon regions can be associated with the variability of total Se concentration in the soil as well as with other soil parameters that control Se availability, such as soil $\mathrm{pH}$. For that purpose, we sampled the fruits and the soil directly under Brazil nut trees across five Brazilian states (Acre, Mato Grosso, Amazonas, Roraima and Amapá) in the Amazon biome. With that, we hope not only to provide information on the role of Brazil nuts as a source of dietary Se to humans, but also to better understand the mechanisms underlying the natural variation of Se in Brazil nuts from different Amazon regions.

\section{Material and methods}

\subsection{Sampling sites and characterization of the study area}

Soil and fruit samples of Brazil nuts were collected in different areas from five sites belonging to the Amazon Biome in five important Brazilian states for production of Brazil nuts: Acre, Mato Grosso, Amazonas, Roraima, and Amapá. For each of these states, the sampling sites were chosen within areas previously studied by the Brazilian Agricultural Research Corporation (Embrapa).

The number of Brazil nut trees sampled in each site was: 15 in the state of Amapá, 14 in the states of Acre and Roraima, 12 in the state of Mato Grosso, and 16 in the state of Amazonas. All the samples were collected in native Amazon rainforest, except in the state of Amazonas, where samples were collected from a Brazil nut plantation known as Aruanã Farm. This tree plantation is located in the municipality of Itacoatiara and was established in 1983, with plants originated from grafting of clones obtained from Embrapa Amazônia Oriental (Belém, state of Pará). This plantation area was subjected to thinning, cleaning, and all the necessary management practices before the plants start to fructify, as well as the maintenance of these plants during the harvest, which differs from the conditions found for other native Brazil nut trees from the Amazon rainforest. According to the local farmers, fertilizers were never applied to the soil in this farm, so it was assumed that the soil Se concentrations reflect natural conditions. In addition, the trees sampled in this farm were all mature and about the same size as those sampled in native Amazon rainforest. According to the farmers, these trees were at least $30-40$ years old.

All the material was collected during the same harvest season in 2014 and 2015, from January to February, except for Brazil nut samples from Roraima, where fruits are produced between March and July. Information concerning geographic coordinates, sampling points and climatic conditions is provided in Fig. 1 and Table 1.

Brazil nuts were sampled below the trees, with ten ripe fruits, which naturally fall from the trees after maturation, being sampled from beneath the canopy. These large fruits (usually with $11-15 \mathrm{~cm}$ in diameter) weigh about $1 \mathrm{~kg}$ and are enclosed by an extremely hard, woody capsule, containing 10-25 seeds in each (Mori and Prance, 1990). To collect the Brazil nuts, these fruits were opened and the nuts were mixed in a plastic bag, from which 50 nuts were randomly sampled and sent to the laboratory for chemical analysis of Se. The method for sampling is represented schematically according to Fig. 2.

Soil samples were collected under each Brazil nut tree crown at the depths of $0-20,20-40$, and $40-60 \mathrm{~cm}$ in a distance of $3 \mathrm{~m}$ from the tree trunk. These samples were collected in 4 points and mixed to compose a single sample for each depth (Fig. 2).

In addition to the soil samples taken beneath the Brazil nut trees, we also sampled soil in a reference area (control) outside the influence of the tree. These control samples were collected at 5 points, within the same topography and drainage conditions in a native forest area, and pooled in order to form a composite sample of each layer (0-20, 20-40, and 40-60 cm) (Fig. S1).

\subsection{Soil samples characterization}

Soil samples were taken to the Soil Science Department of the 


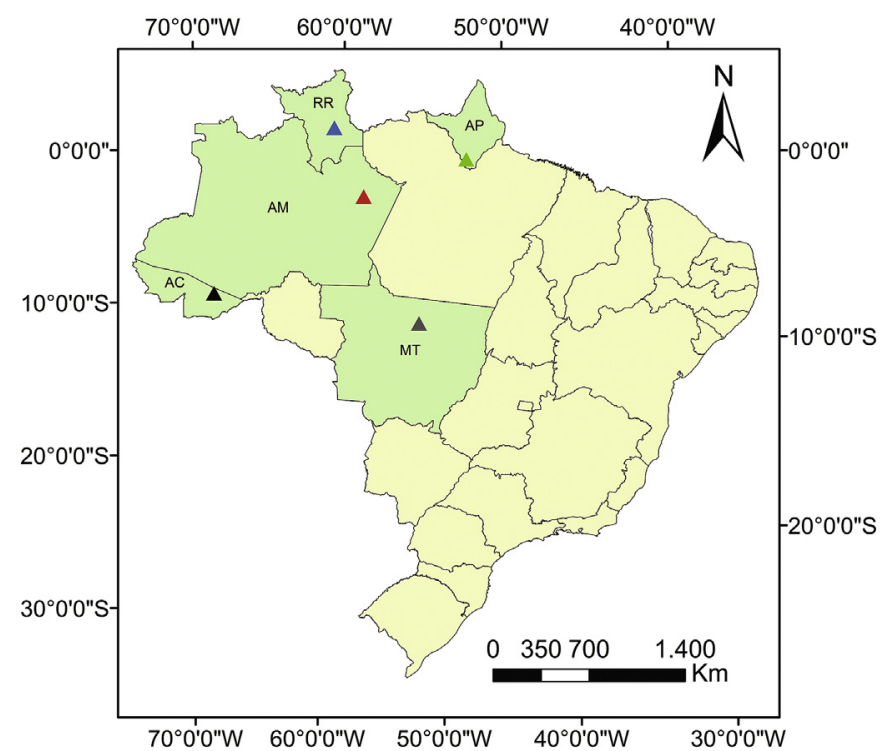

Fig. 1. Location of sampling areas in 5 different states in the Brazilian Amazon region: AC (state of Acre), MT (state of Mato Grosso), AM (state of Amazonas), AP (state of Amapá), and RR (state of Roraima).
$1: 2.5 \mathrm{soil} /$ solution $(10 \mathrm{~g}$ of soil in $25 \mathrm{~mL}$ of either water or $\mathrm{KCl}$ solution) (Raij et al., 2001).

The exchangeable cations $\mathrm{Ca}^{2+}, \mathrm{Mg}^{2+}$ and $\mathrm{Al}^{3+}$ were obtained by extraction with $1 \mathrm{~mol} \mathrm{~L}^{-1} \mathrm{KCl}$. For that, five $\mathrm{g}$ of soil was added to $50 \mathrm{~mL}$ of $1 \mathrm{~mol} \mathrm{~L}^{-1} \mathrm{KCl}$ and then shaken during $5 \mathrm{~min}(220 \mathrm{rpm})$, after which the extracts were immediately filtered (Raij et al., 2001).

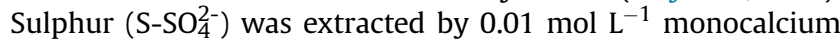
phosphate $\left(\mathrm{Ca}\left(\mathrm{H}_{2} \mathrm{PO}_{4}\right)_{2}\right)$ in acetic acid. For that purpose, $10 \mathrm{~g}$ of soil was added to $100 \mathrm{~mL}$ of extraction solution and then shaken for $30 \mathrm{~min}(220 \mathrm{rpm})$, after which the extracts were filtered (Raij et al., 2001).

The elements $\mathrm{P}, \mathrm{Na}$, K, and available micronutrients ( $\mathrm{Fe}, \mathrm{Zn}$, Mn, and $\mathrm{Cu}$ ) were obtained following the reaction of $10 \mathrm{~g}$ of soil with $100 \mathrm{~mL}$ of the Mehlich-1 extractant $\left(0.05 \mathrm{~mol} \mathrm{~L}^{-1} \mathrm{HCl}+0.0125 \mathrm{~mol} \mathrm{~L}^{-1} \mathrm{H}_{2} \mathrm{SO}_{4}\right)$. This material was shaken for $5 \mathrm{~min}(220 \mathrm{rpm})$ and the extracts were left to decant overnight, after which the aqueous phase was collected (Silva, 1999).

Potential acidity $(\mathrm{H}+\mathrm{Al})$ was estimated indirectly through SMP pH (Shoemaker et al., 1961). Exchangeable aluminum $\left(\mathrm{Al}^{3+}\right)$ was determined by titration with ammonium hydroxide $\left(0.025 \mathrm{~mol} \mathrm{~L}^{-1}\right.$ $\mathrm{NaOH})$. The phosphorus $(\mathrm{P})$ was determined colorimetrically, potassium $(\mathrm{K})$ by flame emission photometry and sulphur $(\mathrm{S})$ by turbidimetry. $\mathrm{Ca}, \mathrm{Mg}$, and micronutrients $(\mathrm{Zn}, \mathrm{Fe}, \mathrm{Mn}$ and $\mathrm{Cu}$ ) were

Table 1

Detailed information of the sampling sites of Brazil nuts and soil samples collection in the Amazon region.

\begin{tabular}{|c|c|c|c|c|}
\hline Municipality/State & \multicolumn{2}{|c|}{ Geographic Coordinates } & Altitude (m) & Climate: Köppen class. \\
\hline Sena Madureira/AC & $9^{\circ} 25^{\prime} 54.59^{\prime \prime} \mathrm{S}$ & $68^{\circ} 35^{\prime} 42.98^{\prime \prime} \mathrm{W}$ & 232 & Am \\
\hline Itaúba/MT & $11^{\circ} 06^{\prime} 00.32^{\prime \prime} \mathrm{S}$ & $55^{\circ} 02^{\prime} 06.78^{\prime \prime} \mathrm{W}$ & 387 & Am \\
\hline Itacoatiara/AM & $3^{\circ} 01^{\prime} 05.59^{\prime \prime} \mathrm{S}$ & $58^{\circ} 49^{\prime} 55.60^{\prime \prime} \mathrm{W}$ & 92 & Af \\
\hline Laranjal do Jari/AP & $0^{\circ} 33^{\prime} 50.61^{\prime \prime} \mathrm{S}$ & $52^{\circ} 18^{\prime} 23.43^{\prime \prime} \mathrm{W}$ & 135 & Am \\
\hline Caracaraí/RR & $1^{\circ} 28^{\prime} 10.09^{\prime \prime} \mathrm{N}$ & $60^{\circ} 44^{\prime} 16.96^{\prime \prime} \mathrm{W}$ & 107 & Am \\
\hline
\end{tabular}

Federal University of Lavras, Minas Gerais, Brazil, where they were dried at room temperature, grinded, sieved, and subjected to chemical and physical (texture) analysis. The soil $\mathrm{pH}$ was determined potentiometrically in water $\left(\mathrm{pH} \mathrm{H}_{2} \mathrm{O}\right)$ and $\mathrm{KCl}\left(1 \mathrm{~mol} \mathrm{~L}^{-1}\right)$ in the ratio

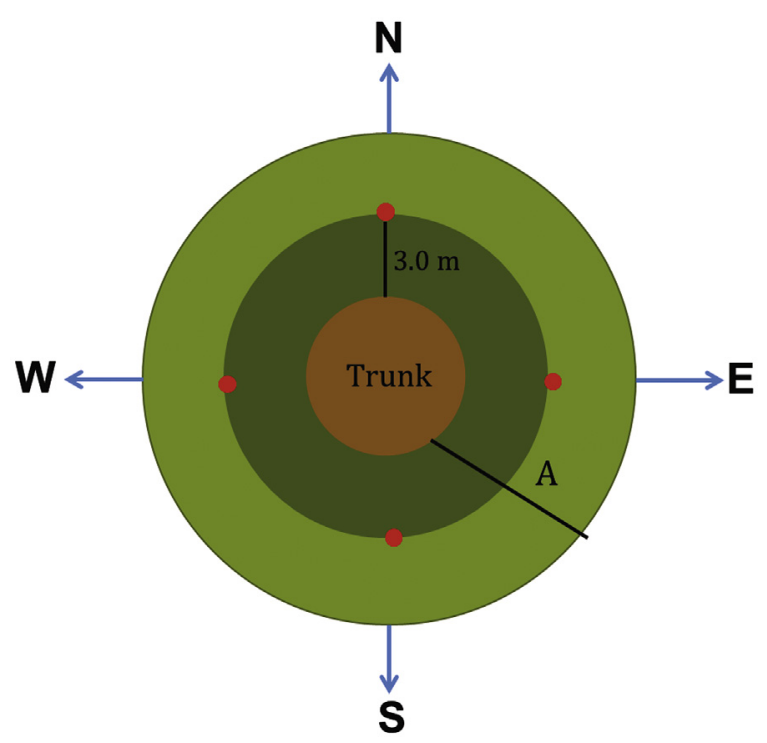

Fig. 2. Sampling scheme. Soil samples were collected in the 4 red points at the $0-20$, $20-40$, and $40-60 \mathrm{~cm}$ depth at a distance of $3 \mathrm{~m}$ from the trunk. Brazil nut fruits were collected under the canopy (A). (For interpretation of the references to colour in this figure legend, the reader is referred to the web version of this article.) determined by atomic absorption spectrometry (AAS) (Raij and Quaggio, 1983).

Sum of bases (SB), cation exchange capacity at $\mathrm{pH} 7$ (T), effective cation exchange capacity $(\mathrm{t})$, base saturation $(\mathrm{V} \%)$, and aluminum saturation $(\mathrm{m})$ were calculated based on the results of the chemical analyses. The particle size analysis (clay, silt, and sand) was performed by the "Bouyoucos" method, as described by Embrapa (1997).

\subsection{Determination of selenium in Brazil nuts}

From the 50 nuts collected from each plant, three nuts were randomly chosen and dried at $60^{\circ} \mathrm{C}$ until reaching constant weight (after about $72 \mathrm{~h}$ ). Initial and final weights were recorded for all samples. After peeling, the average weight of these 3 nuts were calculated in order to obtain the individual Se content of nuts and subsequently they were ground with an electric hand mill. After grinding, $0.5 \mathrm{~g}$ of each sample was taken in triplicate for digestion, using an adaptation of the methodology described by Malavolta et al. (1997). Digestion was performed using $6 \mathrm{~mL}$ of a mixture $(2: 1 \mathrm{v} / \mathrm{v})$ composed by nitric acid $\left(\mathrm{HNO}_{3} \geq 65 \%\right)$ and perchloric acid $\left(\mathrm{HClO}_{4}, 69.72 \%\right)$. The extract was allowed to stand overnight at room temperature and the digestion was performed next morning after a $16 \mathrm{~h}$ resting. In order to digest the samples, a metal digestion block was used, with an initial temperature of $50{ }^{\circ} \mathrm{C}$, which was gradually increased by $50{ }^{\circ} \mathrm{C}$ each 30 min until completing $2 \mathrm{~h}$ of digestion (final temperature of $200{ }^{\circ} \mathrm{C}$ ). Finally, after the digestion procedures, the extract was kept for $15 \mathrm{~min}$ at room temperature to cool down, and then $10 \mathrm{~mL}$ of deionized water was added to each 
extract. The final volume was then poured into $30-\mathrm{mL}$ vials, followed by storage at $5{ }^{\circ} \mathrm{C}$ until analysis.

\subsection{Determination of selenium in soils}

For the determination of total soil Se, $5 \mathrm{~g}$ of dried soil $(<2 \mathrm{~mm})$ was homogenized and grinded with a mortar and agate pestle and passed through a 100 -mesh nylon sieve $(<150 \mu \mathrm{m})$. After that, three aliquots of $0.5 \mathrm{~g}$ were separately taken to perform the $3051 \mathrm{~A}$ digestion method described by the United States Environmental Protection Agency (USEPA, 1998). Each aliquot was digested with $5 \mathrm{~mL}$ of aqua regia (a mixture composed by $\mathrm{HNO}_{3} \geq 65 \%$ and $\mathrm{HCl}$ $37 \%-1: 3 \mathrm{v} / \mathrm{v}$ ) in PTFE Teflon ${ }^{\circledR}$ tubes (CEM Corporation, Matthews, NC, USA). The extract was allowed to stand overnight at room temperature and digestion was performed in the next morning. For that, the vials were hermetically sealed and taken to a microwave (CEM brand, model Mars-5), with a temperature set at $175^{\circ} \mathrm{C}$ and at a controlled pressure of $0.76 \mathrm{MPa}$ for $25 \mathrm{~min}$. After digestion, extracts were cooled down at room temperature and then filtered on a filter paper. Then, the final volume of the extract was supplemented with additional $5 \mathrm{~mL}$ of deionized water at the time of filtration. After filtration, the extracts were transferred into smaller vials $(30 \mathrm{~mL})$ followed by storage at $5{ }^{\circ} \mathrm{C}$ until analysis.

\subsection{Analytical determination of selenium}

Se in the digested Brazil nut and soil samples were analysed by GFAAS (Atomic Absorption Spectrometry with Zeeman background correction and EDL lamp for Se; AAnalyst ${ }^{\mathrm{TM}} 800$ AAS, Perkin Elmer). A standard stock solution containing $1 \mathrm{~g} \mathrm{Se} \mathrm{kg}^{-1}$ ( $\geq 98 \%$ purity, Fluka, Buchs, Switzerland) was used to prepare the calibration curve for Se determination by GFAAS. Data for total Se concentration in Brazil nuts and soils were reported on a dry weight basis (DW) and expressed in $\mathrm{mg} \mathrm{kg}^{-1}$ for Se in Brazil nuts and $\mu \mathrm{g} \mathrm{kg}^{-1}$ for Se in soil samples.

\subsection{Calculation of detection and quantification limits}

The detection and quantification limits (LOD and LOQ) were established using 10 blank extracts following the overall procedure. The values were calculated with three and ten times the standard deviation (LOD and LOQ, respectively) of the 10 individually prepared blank solutions for soil and Brazil nut samples (Khan et al., 2013). For Brazil nuts analysis the LOD ( $\mu$ g of Se $\mathrm{kg}^{-1}$ of extract) was 3.67 ( $\mathrm{LOQ}$ of $12.23 \mu \mathrm{g} \mathrm{kg}^{-1}$ ), whereas for soil analysis the LOD ( $\mu \mathrm{g}$ of Se $\mathrm{kg}^{-1}$ of extract) was 2.05 (LOQ of $6.84 \mu \mathrm{g} \mathrm{kg}^{-1}$ ). The LODs of the analytical methods used for Brazil nuts and soil samples ( $\mu \mathrm{g}$ Se $\mathrm{kg}^{-1}$ sample DW) were 550.17 and 65.76 , respectively.

\subsection{Quality control and statistical analysis}

A sample of standard reference material (White Clover - BCR 402, Institute for Reference Materials and Measurements, Geel, Belgium) for plant material was included in each digestion batch for quality control purposes, along with a blank sample that was used to calculate the limits of detection and quantification. The mean recovery for Se in this standard reference material (white clover) was $97.53 \%$ ( $n=7, \mathrm{SE}=6.27)$.

For soil Se, each digestion batch included two standard reference materials for soil from the National Institute of Standards and Technology (NIST 2710a and NIST 2711a), containing 1 and $2 \mathrm{mg}$ Se $\mathrm{kg}^{-1}$, respectively. The average recovery for Se in the standard reference material was $75.1 \%$ (NIST $2710 a)(n=37, S E=2.30)$ and $75.3 \%$ (NIST $2711 \mathrm{a})(\mathrm{n}=37, \mathrm{SE}=2.08)$. We also used a blank sample in each batch for quality control purposes and for calculating limits of detection and quantification.

To assess how the log-transformed Se concentration in the nuts varied across States, an analysis of variance was performed using generalized least squares, in order to allow the variance to be estimated separately for each State (Cleasby and Nakagawa, 2011). After verifying the significance of State in the anova, the means were compared among States using Tukey's HSD test with the package lsmeans v2.23 (Lenth, 2016) in R 3.2.2 (R Development Core Team, 2016). The same approach was used to compare the soil among states.

To further address the importance of soil variables for the observed variation in Se concentration in the nuts, eight separate regression models (Table 2) were fitted to the data in order to test which of the following hypotheses are better supported by our data:

- Se concentration in the nuts depends only on the total Se concentration in the soil (models 4, 6, and 8);

- Se concentration in the nuts depends on both the total Se concentration and on the soil pH (models 2, 3, and 7);

- Se concentration in the nuts depends on latent gradients of the soil variables obtained through a supervised principal component analysis (models 1 and 5).

These models were ranked through an information-theoretic (IT) approach as suggested by Burnham and Anderson (2002). This approach for model selection has been advocated to avoid the drawbacks of stepwise multiple regression (e.g. bias in parameter estimation, inherent multiple hypothesis testing, inappropriate reliance on a single best model) as discussed in Whittingham et al. (2006). The Akaike information criterion (AIC), a measure of relative quality of a model that combines both goodness of fit and complexity, was used to rank these models (Table 2). As suggested by Burnham and Anderson (2002), differences in AIC greater than 2 were considered strong evidence in favour of the model with lowest AIC.

The latent variables utilized in models 1 and 5 were obtained through supervised principal component analysis (Bair et al., 2006). This analysis is similar to the conventional principal component analysis, except that a subset of the variables (soil properties) are chosen and weighted based on their strength of association with a variable of interest (in the nuts for this study) (Bair et al., 2006). For that purpose, the soil variables were first standardized and their association with the log-transformed Se concentration in the nuts was assessed by their individual regression coefficients as shown in Fig. S4. The selected subset of soil variables was weighted by those coefficients and submitted to a conventional principal component analysis, from which the first two components were extracted and used as explanatory variables in models 1 and 5 (Table 2). Further details on the supervised principal component analysis can be found in Bair et al. (2006).

\section{Results and discussion}

\subsection{Total Se concentration of Brazil nuts}

In this study, fruits and the soil beneath 71 Brazil nut trees were sampled across five Brazilian states (Acre, Mato Grosso, Roraima, Amapá and Amazonas), important producers of Brazil nuts in the Amazon region, in order to assess the variation in Se concentration in Brazil nuts and in their surrounding soil, as well as to investigate the relationship between soil properties and Se accumulation in Brazil nuts in these ecosystems.

Among all samples, the Se concentration in the nuts ranged

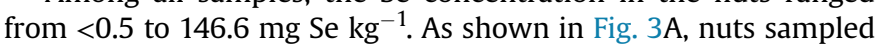
from Amazonas and Amapá states presented the highest Se 
Table 2

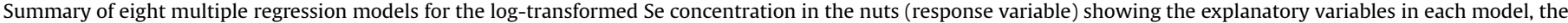

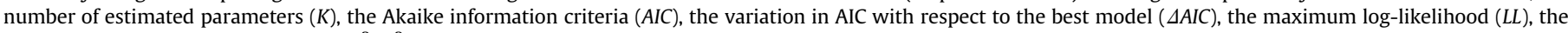
Akaike weights $(w)$, and the adjusted $R^{2}\left(R^{2}\right.$ adj $)$.

\begin{tabular}{|c|c|c|c|c|c|c|c|}
\hline Model & Explanatory Variables & K & AIC & $\Delta A I C$ & $L L$ & $w$ & $R_{a d j}^{2}(\%)$ \\
\hline 1 & $\mathrm{PC} 1+\mathrm{PC} 2$ & 4 & 112.71 & 0.0 & -52.35 & 1 & 47.0 \\
\hline 2 & Soil Se $(0-20 \mathrm{~cm})+\mathrm{pH}_{\mathrm{H} 20}(0-20 \mathrm{~cm})$ & 4 & 131.81 & 19.1 & -61.91 & 0 & 31.2 \\
\hline 3 & Soil Se $(20-40 \mathrm{~cm})+\mathrm{pH}_{\mathrm{H} 20}(20-40 \mathrm{~cm})$ & 4 & 137.43 & 24.7 & -64.71 & 0 & 25.6 \\
\hline 4 & Soil Se $(0-20 \mathrm{~cm})$ & 3 & 138.18 & 25.5 & -66.09 & 0 & 23.9 \\
\hline 5 & PC1 & 3 & 145.72 & 33.0 & -69.86 & 0 & 15.6 \\
\hline 6 & Soil Se $(20-40 \mathrm{~cm})$ & 3 & 146.30 & 33.6 & -70.15 & 0 & 14.9 \\
\hline 7 & Soil Se $(40-60 \mathrm{~cm})+\mathrm{pH}_{\mathrm{H} 20}(40-60 \mathrm{~cm})$ & 4 & 146.34 & 33.6 & -69.17 & 0 & 16.0 \\
\hline 8 & Soil Se $(40-60 \mathrm{~cm})$ & 3 & 153.86 & 41.2 & -73.93 & 0 & 5.6 \\
\hline
\end{tabular}

concentrations (medians of 66.1 and $51.2 \mathrm{mg} \mathrm{Se} \mathrm{kg}^{-1}$, respectively), followed by Roraima (median of $10.2 \mathrm{mg} \mathrm{Se} \mathrm{kg}^{-1}$ ), whereas nuts sampled from Acre and Mato Grosso states presented the lowest Se concentrations (medians of 3.0 and $2.4 \mathrm{mg} \mathrm{Se} \mathrm{kg} \mathrm{g}^{-1}$, respectively). The same pattern was observed for the total Se content per nut, as shown in Fig. 3B. These results are in accordance with a previous study conducted with Brazil nut samples collected from Acre and Rondônia (southern Amazon), where Se concentrations ranged from 0.03 to $31.7 \mathrm{mg} \mathrm{kg}^{-1}$ (fresh weight), as well as in a region located between Manaus-Belém (northern Amazon), where Se concentration ranged between 1.25 and $512.0 \mathrm{mg} \mathrm{kg}^{-1}$ (fresh weight) (Chang et al., 1995). Another study evaluating Se concentrations in Brazil nuts in South America reported values ranging from $5.1 \mathrm{mg} \mathrm{kg}^{-1}$, in nuts from Bolivia, to $49.9 \mathrm{mg} \mathrm{kg}^{-1}$, in nuts from Brazil. Although Se concentration in the soil was not measured, those authors believed that location was the main factor influencing the Se concentration in the nuts, presumably because of the soil where these nuts were obtained (Parekh et al., 2008).

Considering that the recommended daily intake of Se is 60 and $70 \mu \mathrm{g} \mathrm{day}{ }^{-1}$ for adult women and men, respectively (Kipp et al., 2015), our results indicate that a single Brazil nut from the states of Amapá and Amazonas would generally exceed the recommended dietary allowance for an adult per day, whereas about seven nuts from Acre and Mato Grosso would be needed to satisfy this need (Fig. 3B). Taking as a reference the Se recommended daily dose of $70 \mu \mathrm{g} \mathrm{day}^{-1}$ (for men), for example, it is possible to predict how much Se is provided on average (percentage) by eating a single nut from the states of Mato Grosso (11\%), Acre (12\%), Roraima (70\%), Amapá (236\%) and Amazonas (288\%). However, it is important to interpret these results with caution because the sampling scheme used in this study was designed to investigate how soil properties influence Se concentration in the nuts, rather than to provide an extensive survey of Se concentration in the nuts in the Amazon region. As such, the variation of Se concentration in Brazil nuts within each state may be higher than reported here and a more extensive sampling is necessary to confirm the observed differences between states.

The high Se concentration showed by Brazil nuts sampled in many areas of this study call the attention for the use of Brazil nuts as a food source of Se. In the diet it can represent an effective way for increasing the Se status for people who have deficiency of this element. Besides being a rich source of Se, its consumption has advantages over the use of supplements and fortified foods, because it is sustainable, has lower cost and offers lower risk of
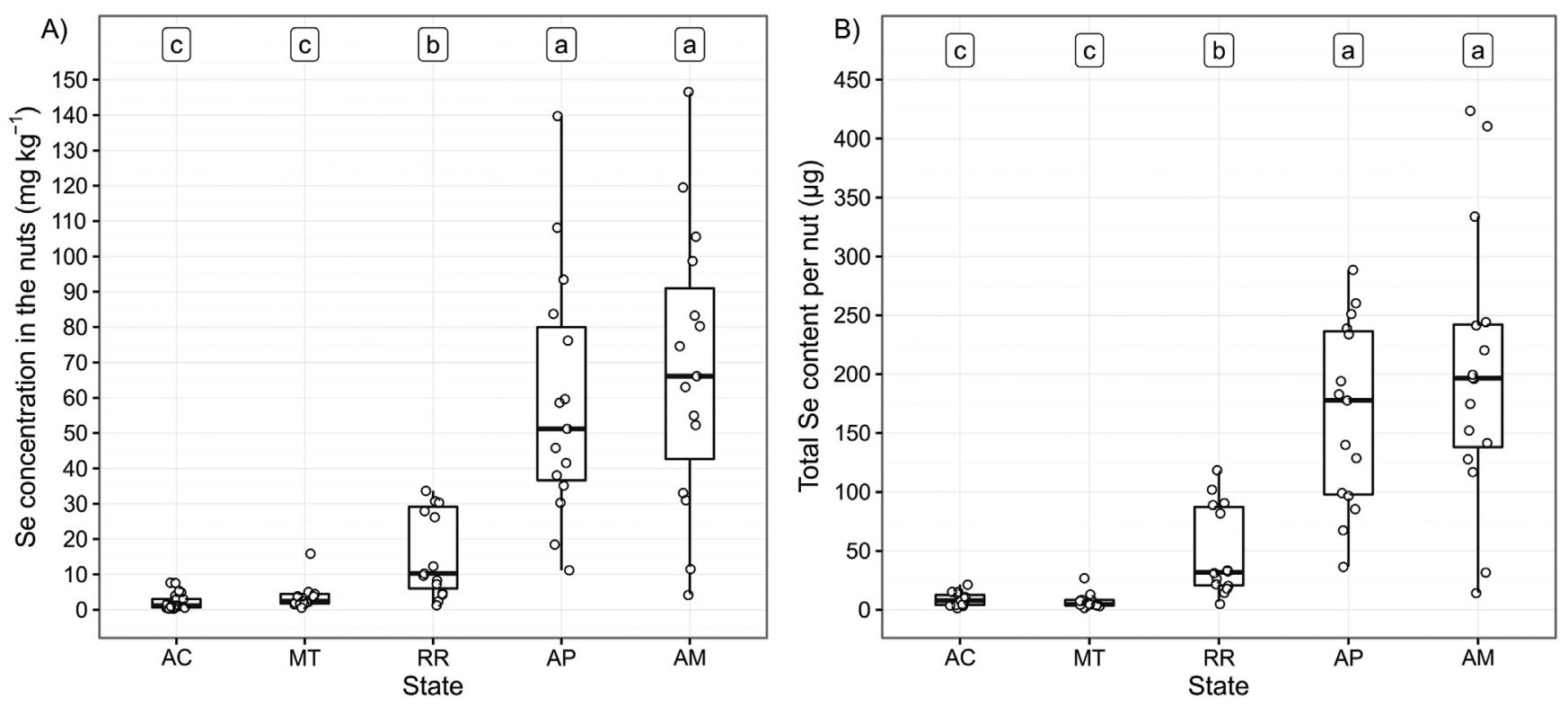

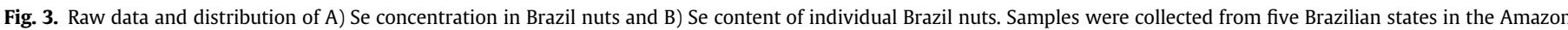

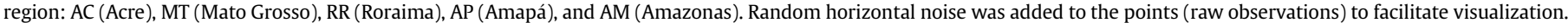

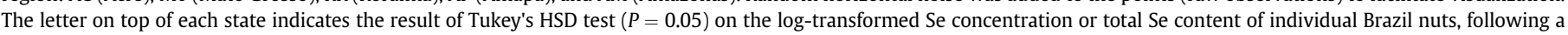
significant ANOVA $(P<0.001)$ using generalized least squares. 
poisoning. The overall recommendation is only one nut a day in the diet to meet the nutritional needs, being effective to increase the Se status and lead to an improvement of glutathione peroxidase (GPx) activity (Cardoso et al., 2015). Yet, Brazil nut recommendations should be made with caution, since barium and radium contents also present in the nuts, are uncertain and may be toxic depending on the amount ingested (Thomson et al., 2008). Moreover, the variation in the total Se concentration shown in this study should also be taken into consideration.

\subsection{Total soil Se concentration}

In the set of soil samples from the five states evaluated at three depths $(0-20,20-40$, and $40-60 \mathrm{~cm})$, total soil Se concentration ranged from $<65.76$ to $625.91 \mu \mathrm{g} \mathrm{kg}^{-1}$ (median of $262.36 \mu \mathrm{g} \mathrm{kg}^{-1}$ ). Only three samples $(\sim 1 \%$ of the total) had total Se concentration below the detection limit $\left(65.76 \mu \mathrm{g} \mathrm{kg}^{-1}\right)$ and $75 \%$ of the soil samples showed values lower than $359.14 \mu \mathrm{g} \mathrm{kg}^{-1}$. In the upper soil layer $(0-20 \mathrm{~cm})$, the median for Se concentration in samples from Amazonas state $\left(476.67 \mu \mathrm{g} \mathrm{kg}^{-1}\right)$ was about two to three-fold higher than those found in samples from Acre $\left(159.22 \mu \mathrm{g} \mathrm{kg}^{-1}\right)$, Roraima (144.32 $\mu \mathrm{g} \mathrm{kg}^{-1}$ ), and Mato Grosso (172.08 $\mu \mathrm{g} \mathrm{kg}^{-1}$ ) (Fig. 4). For soil samples $(0-20 \mathrm{~cm})$ from Amapá state, the median soil Se concentration $\left(291.54 \mu \mathrm{g} \mathrm{kg}^{-1}\right)$ was about $40 \%$ lower than that of Amazonas state, but 1.5-2-fold higher than those from Acre, Mato Grosso, and Roraima. For deeper soil layers (20-40 and 40-60 cm), Se concentrations in samples from the Amazonas state were significantly higher than those found in all the other states, which did not differ among themselves (Fig. 4).

The median values observed in this study for soil samples from the Amazon region were higher than those observed in a study recently performed in the state of São Paulo, Brazil, which reported average Se concentrations of $93 \mu \mathrm{g} \mathrm{kg}{ }^{-1}$ for superficial layers and $127 \mu \mathrm{g} \mathrm{kg}^{-1}$ for subsurface soil samples representative of agricultural areas (Gabos et al., 2014). But these values are within the typical Se concentrations in Brazilian soils in the surface layer $(0-20 \mathrm{~cm})$, as reported by Shaltout et al. (2011): Amazonas (604 $\left.\mathrm{g} \mathrm{kg} \mathrm{k}^{-1}\right)$; Mato Grosso do Sul (113 $\left.\mu \mathrm{g} \mathrm{kg}^{-1}\right)$; Pará $\left(419 \mu \mathrm{g} \mathrm{kg}^{-1}\right)$; Rio Grande do Sul $\left(248 \mu \mathrm{g} \mathrm{kg}^{-1}\right)$; Santa Catarina (262 $\left.\mu \mathrm{g} \mathrm{kg}^{-1}\right)$; Minas Gerais (1692 $\left.\mu \mathrm{g} \mathrm{kg}^{-1}\right)$; Ceará $\left(599 \mu \mathrm{g} \mathrm{kg}^{-1}\right)$; Goiás $\left(215 \mu \mathrm{g} \mathrm{kg}^{-1}\right)$ and Paraná $\left(370 \mu \mathrm{g} \mathrm{kg}^{-1}\right)$. The majority of the soils analysed in the current study are within the "normal" range of Se concentration $\left(<500 \mu \mathrm{g} \mathrm{kg}^{-1} \mathrm{Se}\right)$, whereas a few in the Amazonas (AM) state are in the moderate toxic range (500-2000 $\mu \mathrm{g} \mathrm{kg}^{-1} \mathrm{Se}$ ) as defined by Dhillon and Dhillon (2014).

An increase in Se concentration with soil depth, as observed in soils from Acre, Mato Grosso, and Roraima, has been previously reported for other Brazilian oxidic soils (Gabos et al., 2014). This may be related to the strong affinity of Se species to positive charges on the surface of iron and aluminum oxides (Goldberg, 2013), abundantly found in the clay fraction of these soils. In the subsurface, the contribution of negative charges from organic matter is reduced, and the positive charges from these oxides may predominate, giving the soil a net positive charge. In addition, the increase in clay content with soil depth (Table S1) may also contribute to higher retention of Se in subsurface (Abreu et al., 2011; De Temmerman et al., 2014; Lessa et al., 2016). Finally, the intense rainfall, typical of those regions, may also lead to Se leaching from upper layers to the subsurface (Sharma and Singh, 1983; Tuttle et al., 2014).

Soils from the state of Amazonas have the highest Se concentrations compared with soils sampled in other states, and these values are considered high in a regional context but not necessarily high in a global scale (Oldfield, 2002). The geographical distribution of soil Se concentration in the 5 sites selected for sampling has a quite interesting relationship with the position of the Amazon River

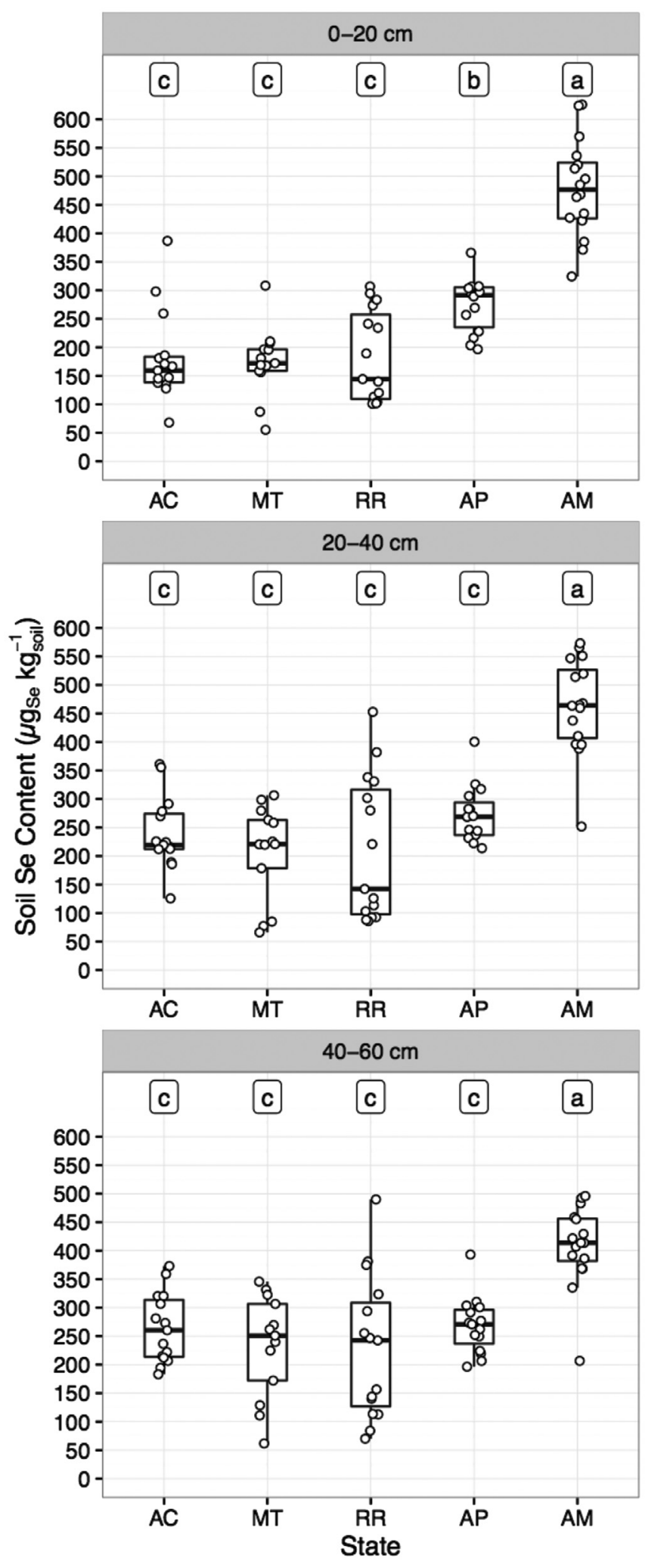

Fig. 4. Raw data and distribution of total soil Se concentration in samples collected at three depths $(0-20,20-40$, and $40-60 \mathrm{~cm})$ in different states of the Amazon region (AC, Acre; MT, Mato Grosso; RR, Roraima; AP, Amapá; and AM, Amazonas). Random horizontal noise was added to the points (raw observations) to facilitate visualization. The letter on top of each state indicates the result of Tukey's test $(P=0.05)$ on the soil Se content, following a significant ANOVA (using generalized least squares due to heteroscedasticity) $(P<0.001)$ for each soil depth separately. 
mainstream in the Amazon Basin. Sites presenting soils with higher Se concentration were located closer to the Amazon river (Amapá and Amazonas), having a distance of approximately $70 \mathrm{~km}$ and $30 \mathrm{~km}$, respectively. On the other hand the sites located more distant (Acre and Mato Grosso, with a distance of approximately $900 \mathrm{~km}$ and $1000 \mathrm{~km}$ ) presented soil with the lowest Se concentrations. Evidences show that the current soil Se distribution in the Amazon Basin received influences from deposition of sediments coming from the Andean volcanic activity in the past (Stallard and Edmond, 1983).

\subsection{Relationship between soil properties and Se concentration in the nuts}

Although $98 \%$ of the soils sampled in this study had Se concentrations below $600 \mu \mathrm{g} \mathrm{kg}^{-1}$, being classified as Se-deficient soils (Gupta and Gupta, 2000; Lyons et al., 2003), Brazil nut trees growing in these soils were remarkably efficient to accumulate Se, especially for samples from AM and AP, for which Se concentrations in the nuts were about two orders of magnitude higher than the total Se concentration found in these soil. Even for trees growing in very Se-poor soils, such as those found in samples from Acre, Roraima, and Mato Grosso, the Se concentrations in the nuts were still about one order of magnitude higher than the Se concentration in the soil.

In order to investigate how soil variables may explain the observed variations in nuts Se concentration, we fitted eight separate regression models for the log-transformed nuts Se concentration, which were ranked using an information-theoretic approach (Burnham and Anderson, 2002) as shown in Table 2. These models included the effect of soil Se concentration alone (models 4, 6, and 8 ) or combined with soil pH (models 2, 3, and 7) for each layer, or the effects of the principal components calculated from soil properties (models 1 and 5) (Table 2). Differences in the Akaike information criteria (AIC) higher than 2 between two models are considered strong evidence in favour of the model with lower AIC (Burnham and Anderson, 2002). Based on this criteria, the models including the effect of soil Se concentration alone performed poorly as indicated by their higher AIC values in comparison to model 1, especially for the deeper layers.

The inclusion of soil $\mathrm{pH}$ improved the models considerably as indicated by their lower AIC (and higher $\mathrm{R}^{2}$ adj) values in relation to the models with only soil Se concentration as explanatory variable, especially for the $0-20 \mathrm{~cm}$ layer. However, the model including the two principal components (PC1 and PC2) as explanatory variables was far superior than the others, indicating that, by combining information of several soil properties, these principal components captured latent soil properties that are related to the Se concentration in the nuts, which were not directly evident from any of the measured variables. For instance, in Fig. 5A, the PC1 (horizontal axis) indicates a clear gradient of increasing soil fertility and decreasing acidity from left to right.

On the other hand, the PC2 (vertical axis) reflects the soil Se concentration in the three layers, which are strongly correlated with the sulphur and clay content. The predicted values of Se concentration based on model 1 (Table 2) are shown in Fig. 5B. Based on this model, the Se concentration in the nuts increases with increasing values of PC1 and decreases with increasing values of $\mathrm{PC} 2$, which is coherent with the original data on Se concentration displayed as the points sizes in Fig. 5A.

These two components seem to reflect two mechanisms by which Se availability in the soil can be increased. Because of the mineralogy of their clay fraction, rich in Fe and $\mathrm{Al}$ oxides, tropical soils can have net positive surface charges under acidic conditions (Fontes et al., 2001), which give them the ability to strongly adsorb anions such as phosphate and selenite/selenate on the clay surface, reducing their availability to the plants (Abreu et al., 2011). Therefore, the increase in nuts Se concentration toward higher values of PC1 seems to reflect reduced adsorption and, consequently, higher availability of Se species in more fertile and less acidic conditions. On the other hand, the PC2 reflects the increase of Se availability in the soil due to increases in total Se concentration, regardless the soil $\mathrm{pH}$. Therefore, despite being acidic and nutrient poor, the soils from Amazonas (AM) are able to keep high Se availability in the soil through their exceedingly high total Se concentration, which compensate for their higher capacity to adsorb anions. On the other hand, the soils from Amapá, despite having low total Se concentration as compared to soils from Amazonas, are possibly able to keep moderate Se availability in the soil by having lower acidity and reduced capacity of anion adsorption. The soils from Roraima (RR) have intermediate soil conditions along these two gradients, which explain their intermediate concentrations of Se in the nuts. Finally, the low concentration of Se in the nuts from Acre and Mato Grosso is consistent with their low soil Se concentration and their acidic conditions indicated by their position along the soil gradient in Fig. 5A.

The influence of total Se concentration in the soil on Se uptake by plants in agricultural systems has been extensively reported (Zhao et al., 2005; Huang et al., 2009; Wang et al., 2012). However, other factors that control Se availability in the soil (e.g. soil pH, organic matter, clay content) are known to influence Se uptake by plants (Gissel-Nielsen, 1971; Johnsson, 1991; Chilimba et al., 2011; De Temmerman et al., 2014; Statwick and Sher, 2017). As in our study, the first to directly relate soil properties and Se accumulation in Brazil nuts, these studies indicate that total Se concentration in the soil has a limited contribution to Se uptake by plants and it must be interpreted in the context of other soil properties that control Se availability. In addition, plant variability is also a factor to be considered, since there is a wide variability in Se contents among nuts collected from plants grown in the same site.

\section{Conclusions}

Variation in the Se concentration in Brazil nuts are considerably wide throughout the Amazon region, with the median nuts Se concentration in Amapá (50.93 $\mathrm{mg} \mathrm{kg}^{-1}$ ) and Amazonas (68.15 $\mathrm{mg} \mathrm{kg}^{-1}$ ) states being more than 20 times higher than those observed for nuts from Acre (2.52 $\mathrm{mg} \mathrm{kg}^{-1}$ ) and Mato Grosso ( $2.07 \mathrm{mg} \mathrm{kg}^{-1}$ ), and about 5 times higher than that observed for the Roraima state $\left(9.96 \mathrm{mg} \mathrm{kg}^{-1}\right)$. Consequently, recommendations of dietary intake of Brazil nuts should take into account their origin, because a single Brazil nut could provide from $11 \%$ (in the Mato Grosso state) up to $288 \%$ (in the Amazonas state) of the daily Se requirement for an adult man $(70 \mu \mathrm{g})$.

The total Se concentration in the soil, by itself, does not satisfactorily explain the observed variability in nuts Se concentration among Brazilian states. However, when the soil properties are analysed together, two strong gradients influencing Se accumulation in the nuts can be observed. One related to the soil acidity, and consequently with Se adsorption in tropical soils; the other related to total Se concentration in the soil.

Our sampling scheme successfully addressed the objective of this study, assessing the relationship among soil properties and Se accumulation in Brazil nuts, but it was not designed to extrapolate the measured nut Se concentrations to the entire state, what would be beyond the objectives of the current study. Therefore, care should be taken when extrapolating these nuts Se concentration for each state because a more comprehensive sampling may be necessary to represent the genetic and environmental variability in each of them. 


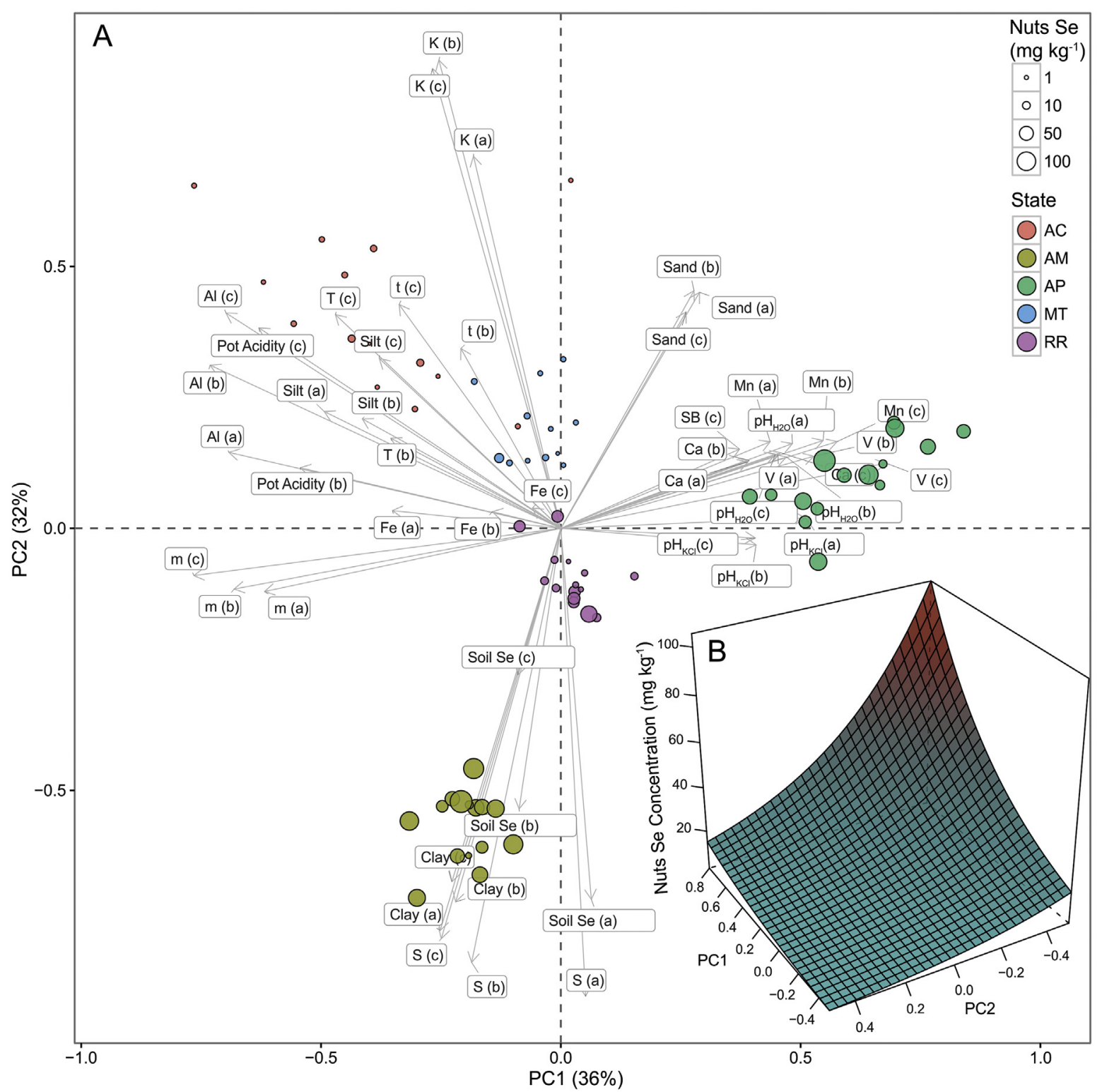

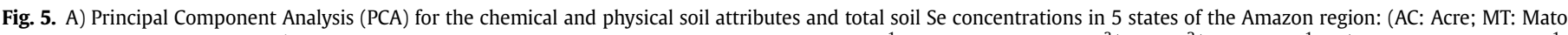

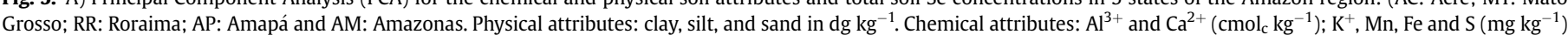

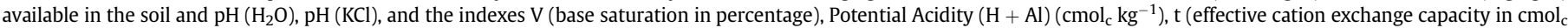

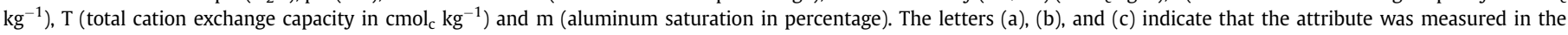

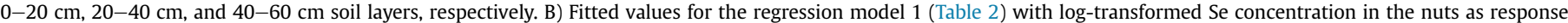
variable and the two principal components as explanatory variables. The fitted values were back-transformed to the original scale ( $\mathrm{mg} \mathrm{kg}^{-1}$ ).

\section{Acknowledgments}

The authors and E.C. Silva Júnior are grateful to CNPq, CAPES and FAPEMIG from Brazil for financial support to the research project and especially FAPEMIG for granting the scholarship during his master degree. We thank the owners of the Aruanã farm in Itacoatiara-AM in the name of Sergio Vergueiro and Ana Vergueiro along with their workers for supporting and hosting us during the samples collection in the farm. We thank the institutions Federal University of Lavras, São Paulo State University (UNESP-Tupã) and all the EMBRAPA's units involved in the present work for assistance during samples collections of soil and Brazil nuts, and the great help given by the laboratory technicians involved in Se analytical determinations, Geila Carvalho and João Gualberto. We also thank three anonymous reviewers for their helpful suggestions on the original manuscript.

\section{Appendix A. Supplementary data}

Supplementary data related to this article can be found at https://doi.org/10.1016/j.chemosphere.2017.08.158.

\section{References}

Abreu, L.B., Carvalho, G.S., Curi, N., Guilherme, L.R.G., Marques, J.J.G.S.M., 2011. Sorção de selênio em solos do bioma cerrado. Rev. Bras. Ciência do solo 35, 1995-2003.

Bair, E., Hastie, T., Paul, D., Tibshirani, R., 2006. Prediction by supervised principal components. J. Am. Stat. Assoc. 101, 119-137.

Bajaj, M., Eiche, E., Neumann, T., Winter, J., Gallert, C., 2011. Hazardous concentrations of selenium in soil and groundwater in North-West India. J. Hazard. Mater. 189, 640-646.

Burnham, K.P., Anderson, D.R., 2002. Model Selection and Multimodel Inference: a Practical Information-theoretical Approach, second ed. Springer-Verlag, New 
York.

Cardoso, B.R., Busse, A.L., Hare, D.J., Cominetti, C., Horst, M.A., Mccoll, G. Magaldi, R.M., Jacob-Filho, W., Cozzolino, S.M.F., 2015. Pro198Leu polymorphism affects the selenium status and GPx activity in response to Brazil nut intake. Food \& Funct. 7, 825-833.

Chang, J.C., Gutenmann, W.H., Reid, C.M., Lisk, D.J., 1995. Selenium content of Brazil nuts from two geographic locations in Brazil. Chemosphere 30, 801-802.

Chilimba, A.D.C., Young, S.D., Black, C.R., Rogerson, K.B., Ander, E.L., Watts, M.J., Lammel, J., Broadley, M.R., 2011. Maize grain and soil surveys reveal suboptimal dietary selenium intake is widespread in Malawi. Sci. Rep. 72, 1-9.

Cleasby, I.R., Nakagawa, S., 2011. Neglected biological patterns in the residuals. Behav. Ecol. Sociobiol. 65, 2361-2372.

Cominetti, C., De Bortoli, M.C., Garrido, A.B., Cozzolino, S.M.F., 2012. Brazilian nut consumption improves selenium status and glutathione peroxidase activity and reduces atherogenic risk in obese women. Nutr. Res. 32, 403-407.

De Temmerman, L., Waegeneers, N., Thiry, C., Du Laing, G., Tack, F., Ruttens, A., 2014 Selenium content of Belgian cultivated soils and its uptake by field crops and vegetables. Sci. total Environ. 468-469, 77-82.

Dhillon, K.S., Dhillon, S.K., 2014. Development and mapping of seleniferous soils in northwestern India. Chemosphere 99, 56-63.

Dumont, E., De Pauw, L., Vanhaecke, F., Cornelis, R., 2006. Speciation of Se in Bertholletia excelsa (Brazil nut): a hard nut to crack? Food Chem. 95, 684-692.

Empresa Brasileira de Pesquisa Agropecuária - EMBRAPA, 1997. Manual de métodos de análise de solo. Rio de Janeiro, second ed., p. 212

Fontes, M.P.F., Camargo, O.A., Sposito, G., 2001. Eletroquímica das partículas coloidais e sua relação com a mineralogia de solos altamente intemperizados. Sci. Agric. 58, 627-646.

Fordyce, F.M., 2007. Selenium geochemistry and health. Ambio J. Hum. Environ. 36, 94-97.

Gabos, M.B., Alleoni, L.R.F., Abreu, C.A., 2014. Background levels of selenium in some selected Brazilian tropical soils. J. Geochem. Explor. 145, 35-39.

Gissel-Nielsen, G., 1971. Influence of $\mathrm{pH}$ and texture of the soil on plant uptake of added selenium. J. Agric. Food Chem. 19, 1165-1167.

Goldberg, S., 2013. Modeling selenite adsorption envelopes on oxides, clay minerals, and soils using the triple layer model. Soil Sci. Soc. Am. J. 77, 64-71.

Gupta, U.C., Gupta, S.C., 2000. Selenium in soils and crops, its deficiencies in livestock and humans: implications for management. Commun. Soil Sci. Plant Anal. 31 (11-14), 1791-1807.

Huang, S., Hua, M., Feng, J., Zhong, X., Jin, Y., Zhu, B., Lu, H., 2009. Assessment of selenium pollution in agricultural soils in the xuzhou district, northwest Jiangsu, China. J. Environ. Sci. 21, 481-487.

Institute of Medicine, 2000. Food and nutrition board. In: Dietary References Intakes for Vitamin C, Vitamin E, Selenium and Carotenoids. National Academy Press, Washington.

Johnsson, L., 1991. Selenium uptake by plants as a function of soil type, organic matter content and pH. Plant Soil 133, 57-64.

Khan, N., Jeong, I.S., Hwang, I.M., Kim, J.S., Choi, S.H., Nho, E.Y., Choi, J.Y., Kwak, B.M., Ahn, J.H., Yoon, T., Kim, K.S., 2013. Method validation for simultaneous determination of chromium, molybdenum and selenium in infant formulas by ICPOES and ICP-MS. Food Chem. 141, 3566-3570.

Kipp, A.P., Strohm, D., Brigelius-Flohé, R., Schomburg, L., Bechthold, A., LeschikBonnet, E., Heseker, H., 2015. Revised reference values for selenium intake. J. Trace Elem. Med. Biol. 32, 195-199.

Lemire, M., Philibert, A., Fillion, M., Passos, C.J.S., Guimarães, J.R.D., Barbosa Jr., F, Mergler, D., 2012. No evidence of selenosis from a selenium-rich diet in the Brazilian Amazon. Environ. Int. 40, 128-136.

Lenth, R.V., 2016. Least-squares means: the R package lsmeans. J. Stat. Softw. 69, $1-33$.

Lessa, J.H.L., Araujo, A.M., Silva, G.N.T., Guilherme, L.R.G., Lopes, G., 2016. Adsorption-desorption reactions of selenium (VI) in tropical cultivated and uncultivated soils under Cerrado biome. Chemosphere 164, 271-277.

Li, Z., Liang, D., Peng, Q., Cui, Z., Huang, J., Lin, Z., 2017. Interaction between selenium and soil organic matter and its impact on soil selenium bioavailability: a review. Geoderma 295, 69-79.

Lyons, G., Stangoulis, J., Graham, R., 2003. High-selenium wheat: biofortification for better health. Nutr. Res. Rev. 16, 45-60.

Malavolta, E., Vitti, G.C., Oliveira, S.A., 1997. Avaliação do estado nutricional das plantas: princípios e aplicações, second ed. POTAFOS, Piracicaba, p. 319.

Mori, S.A., Prance, G.T., 1990. Taxonomy, ecology, and economic botany of the Brazil nut (bertholletia excelsa humb. \& bonpl.: lecythidaceae). Adv. Econ. Bot. 8, 130-150.

Nothstein, A.K., Eiche, E., Riemann, M., Nick, P., Winkel, L.H.E., Göttlicher, J., Steininger, R., Brendel, R., Brasch, M.V., Konrad, G., Neumann, T., 2016. Tracking Se assimilation and speciation through the rice Plant-Nutrient competition, toxicity and distribution. PLoS One 11, 1-15.
Oldfield, J.E., 2002. Selenium World Atlas: Updated Edition. Selenium-tellurium Development Association.

Pacheco, A.M., Scussel, V.M., 2007. Selenium and aflatoxin levels in raw Brazil nuts from the Amazon basin. J. Agric. Food Chem. 55, 11087-11092.

Parekh, P.P., Khan, A.R., Torres, M.A., Kitto, M.E., 2008. Concentrations of selenium, barium, and radium in Brazil nuts. J. Food Compos. Anal. 21, 332-335.

Raij, B.V., Quaggio, J.A., 1983. Métodos de análise de solo para fins de fertilidade, vol 81. Instituto Agronômico Boletim técnico, Campinas, p. 31.

Raij, B., Van Andrade, I.C., de Cantarela, H., Quaggio, J.A., 2001. Análise química para avaliação da fertilidade de solos tropicais. Instituto Agronômico, Campinas, p. 285.

Rayman, M.P., 2012. Selenium and human health. Lancet 379, 1256-1268.

R Development Core Team, 2016. R: a Language and Environment for Statistical Computing. R Foundation for Statistical Computing, Vienna, Austria, Version 3.2.2. .

Reilly, C., 1999. Brazil nuts-the selenium supplement of choice? BNF Nutr. Bull. 23, 177-184.

Secor, C.L., Lisk, D.J., 1989. Variation in the selenium content of individual Brazil nuts. J. food Saf. 9, 279-281.

Shaltout, A.A., Castilho, I.N.B., Welz, B., Carasek, E., Martens, I.B.G., Martens, A Cozzolino, S.M.F., 2011. Method development and optimization for the determination of selenium in bean and soil samples using hydride generation electrothermal atomic absorption spectrometry. Talanta 85, 1350-1356.

Sharma, S., Singh, R., 1983. Selenium in soil, plant, and animal systems. Crit. Rev. Environ. Control 13, 23-49.

Shepard, G.H.J., Ramirez, H.E.R., 2011. "Made in Brazil": human dispersal of the Brazil nut (Bertholletia excelsa, lecythidaceae ) in ancient amazonia. Econ. Bot. $65,44-65$.

Shoemaker, H.E., McLean, E.O., Pratt, P.F., 1961. Buffer methods for determining lime requirement of soils with appreciable amounts of extractable aluminum. Proc. Soil Sci. Soc. Am. J. 25, 274-277.

Silva, F.C., 1999. Manual de análises químicas de solos, plantas e fertilizantes. EMBRAPA, Brasília, p. 370.

Stallard, R.F., Edmond, J.M., 1983. Geochemistry of the Amazon: 2. The influence of geology and weathering environment on the dissolved load. J. Geophys. Res. 88, 9671-9688.

Statwick, J., Sher, A.A., 2017. Selenium in soils of western Colorado. J. Arid Environ. $137,1-6$.

Stockler-Pinto, M.B., Mafra, D., Moraes, C., Lobo, J., Boaventura, G.T., Farage, N.E. Silva, W.S., Cozzolino, S.F., Malm, O., 2014. Brazil nut (Bertholletia excelsa, H.B.K.) improves oxidative stress and inflammation biomarkers in hemodialysis patients. Biol. Trace Elem. Res. 158, 105-112.

Stockler-Pinto, M.B., Carrero, J.J., Weide, L.C.C., Cozzolino, S.M.F., Mafra, D., 2015 Effect of selenium supplementation via Brazil Nut (Bertholletia Excelsa, Hbk) on thyroid hormones Levels in hemodialysis patients: a pilot study. Nutr. Hosp. 32 1808-1812.

Thomson, C.D., Chisholm, A., Mclachlan, S.K., Campbell, J.M., 2008. Brazil nuts: an effective way to improve selenium status. Am. J. Clin. Nutr. 87, 379-384.

Tolu, J., Thiry, Y., Bueno, M., Jolivet, C., Potin-Gautier, M., Le Hécho, I., 2014. Distribution and speciation of ambient selenium in contrasted soils, from mineral to organic rich. Sci. Total Environ. 479-480, 93-101.

Tuttle, M.L.W., Fahy, J.W., Elliott, J.G., Grauch, R.I., Stillings, L.L., 2014. Contaminants from Cretaceous black shale: I. Natural weathering processes controlling contaminant cycling in Mancos Shale, southwestern United States, with emphasis on salinity and selenium. Appl. Geochem. 46, 57-71.

United States Environmental Protection Agency, 1998. Test Methods for Evaluation Solid Waste Physical and Chemical Methods: Microwave Assisted Acid Digest of Sediments, Sludges, Soils and Oils, p. 98. SW-846. Washington.

Vriens, B., Behra, R., Voegelin, A., Zupanic, A., Winkel, L.H.E., 2016. Selenium uptake and methylation by the microalga chlamydomonas reinhardtii. Environ. Sci. Technol. 50, 711-720.

Wang, S., Liang, D., Wang, D., Wei, W., Fu, D., Lin, Z.-Q., 2012. Selenium fractionation and speciation in agriculture soils and accumulation in corn (Zea mays L.) under field conditions in Shaanxi Province, China. Sci. Total Environ. 427-428, $159-164$.

Whittingham, M.J., Stephens, P.A., Bradbury, R.B., Freckleton, R.P., 2006. Why do we still use stepwise modelling in ecology and behaviour? J. Animal Ecol. 75, $1182-1189$.

Winkel, L.H.E., Vriens, B., Jones, G.D., Schneider, L.S., Pilon-Smits, E., Bañuelos, G.S. 2015. Selenium cycling across soil-plant-atmosphere interfaces: a critical review. Nutrients 7, 4199-4239.

Yee, H.S., Measures, C.I., Edmond, J.M., 1987. Selenium in the tributaries of the Orinoco in Venezuela. Nature 329, 219-222.

Zhao, C., Ren, J., Xue, C., Lin, E., 2005. Study on the relationship between soil selenium and plant selenium uptake. Plant Soil 277, 197-206. 